\title{
Áhrif hjartaendurhæfingar HL-stöðvarinnar eftir kransæðahjáveituaðgerð eða annað kransæðainngrip
}

\author{
Fríða Dröfn Ammendrup tölvunarfræðingur, Mundína Ásdís Kristinsdóttir² sjúkrapjálfari, Gunnar Guðmundsson²,3 læknir, \\ Erlingur Jóhannsson ${ }^{1}$ lífeðlisfræðingur
}

\section{ÁGRIP}

Inngangur: Hjartaendurhæfing er viðurkennd meðferð hjá sjúklingum með kransæðasjúkdóma en takmarkaðar upplýsingar eru til um hana á Íslandi. Markmið pessarar rannsóknar var að kanna hvort hjartaendurhæfing á stigi II i HL-stöðinni eftir kransæðahjáveituaðgerð eða kransæðavíkkun, skilaði bættri líkamlegri heilsu og betri lífsgæðum til sjúklinga. Efniviður og aðferðir: Sjúklingar sem gengist höfðu undir inngrip vegna kransæðasjúkdóms var boðin pátttaka. Alls páðu 64 boðið (af 65) en 48 luku pátttöku i rannsókninni. Að meðaltali mættu pátttakendur i 2,1 skipti á viku i 8,4 vikur. Mælingar gerðar: prektala (W/kg), blóðprýstings- og púlssvörun úr áreynsluprófi og líkamspyngdarstuðull $\left(\mathrm{kg} / \mathrm{m}^{2}\right)$. Til að meta heilsutengd lífsgæði var notaður SF-36v2 lífsgæðakvarðinn.

Niðurstöður: Prek batnaði um 14,4\% ( $p<0,001)$ og 6,1\% aukning varð á hámarkspúlsi $(p=0,001)$. Pátttakendum var skipt upp í tvo hópa eftir aldri
(32-64 ára og 65-86 ára) og bættu báđir aldurshópar sig svipað í preki (14,6\% og 14,1\%) en pað var eingöngu eldri hópurinn sem jók hámarkspúls marktækt eða um $7,2 \%(p=0,007)$. Pegar pátttakendum var skipt i tvo hópa eftir pví hversu oft peir æfðu á viku kom fram 10,1\% aukning á prektölu hjá hópnum sem æfði sjaldnar en 19,8\% hjá peim sem æfðu oftar $(p<0,001)$. Pátttakendur mátu líkamlega líðan, mælda með̃ spurningalista um lífsgæði, betri við lok pjálfunar $(p=0,003)$ en ekki andlega líđan $(p=0,314)$. Pegar pátttakendum var skipt í tvo hópa eftir pví hvernig peir mátu líkamlega líðan í upphafi rannsóknar varð marktæk hækkun um 15,1\% á líkamlegri líðan hjá peim sem mátu sig í verri stöđu i upphafi ( $p=0,002)$, en hinn hópurinn hækkaði um $1,2 \%$.

Ályktun: Hjartaendurhæfing bætir prek og líkamlega vellíðan. Magn pjálfunar hefur áhrif á bætingu i breki.
Fyrirspurnir: Erlingur Jóhannsson erljo@hi.is

Greinin barst

13. apríl 2015 sampykkt til birtingar

1. október 2015

Höfundar hafa útfyllt eyðublað um hagsmunatengsl.

\section{Inngangur}

Kransæðasjúkdómar eru algengir í hinum vestræna heimi ${ }^{1,2}$ og mikill árangur hefur náðst í meðferð peirra eins og komið hefur fram í tveimur nýlegum yfirlitsgreinum í Læknablaðinu. ${ }^{3,4}$ Hjartaendurhæfing er vel ígrunduð meðferð hjá sjúklingum með kransæðasjúkdóma og komin er mikil og áralöng reynsla á pví sviði. ${ }^{5-7}$ Fáar nýlegar rannsóknir hafa verið framkvæmdar á pessu sviði á Íslandi, ${ }^{8}$ en fjölmargar rannsóknir hafa verið gerðar erlendis. ${ }^{9-11}$ Endurteknar safngreiningar hafa sýnt að endurhæfing sjúklinga með kransæðasjúkdóma leiðir til meiri lífsgæða og dregur úr dánartíðni. ${ }^{5,6 "}$

Hjartaendurhæfing felst yfirleitt í einhvers konar hreyfingu, en auk pess spilar fræðsla og forvarnarstarf stóran pátt. ${ }^{12}$ Hjartaendurhæfing skiptist í prjú stig. ${ }^{13}$ Stig I pjálfun fer yfirleitt fram inni á sjúkrahúsum strax að sjúkrahúsmeðferð lokinni. Stig II endurhæfing fer fram á endurhæfingarstöðvum og eru sjúklingar undir nákvæmu eftirliti og stendur endurhæfingin gjarnan í 4-6 vikur. Stig III hjartaendurhæfing er viðhaldsmeðferð undir eftirliti og getur staðið árum saman. ${ }^{14 "}$

Hjarta- og lungnaendurhæfingarstöðin í Reykjavík (HL-stöðin) hefur starfað frá 1986 og fer par meðal annars fram endurhæfing kransæðasjúklinga eftir kransæðahjáveituaðgerðir og kransæðavíkkun með eða án stoðnetsísetningar. Fylgt er viðurkenndum al- pjóðlegum leiðbeiningum varðandi framkvæmd hjartaendurhæfingar. ${ }^{15,16}$

Pótt vitað sé um ótvírætt gildi hjartaendurhæfingar er ekki eins vel pekkt hvaða pjálfun hentar best fyrir pessa sjúklinga, né hversu mikil pjálfunin á að vera, bæði með tilliti til ákefðar og magns pjálfunar. Einnig eru ekki skýrar vísbendingar um hversu lengi slík endurhæfing á að standa yfir..$^{5-7}$

Í ljósi pessa var markmið pessarar rannsóknar í fyrsta lagi að kanna hvort Stig II pjálfun í HL-stöðinni skilaði mælanlegum árangri í bættri líkamlegri heilsu og meiri lífsgæðum sjúklinga. Í öðru lagi var tilgangurinn að skoða hversu mikil pjálfunin á að vera svo fram komi jákvæð áhrif á prek pátttakenda.

\section{Efniviður og aðferðir}

\section{Val á pátttakendum}

Öllum sjúklingum sem gengist höfðu undir inngrip vegna kransæðasjúkdóms og hófu hjartaendurhæfingu á HL-stöðinni frá febrúar til september 2012 var boðin pátttaka í rannsókninni. Einn hafnaði pátttöku en 64 sampykktu hana. Leyfi til rannsóknar var fengið frá Vísindasiðanefnd (VSN 11-168-S1) og yfirlækni HLstöðvar og var rannsókn tilkynnt til Persónuverndar (S5511/2011). Allir pátttakendur fengu kynningarbréf 


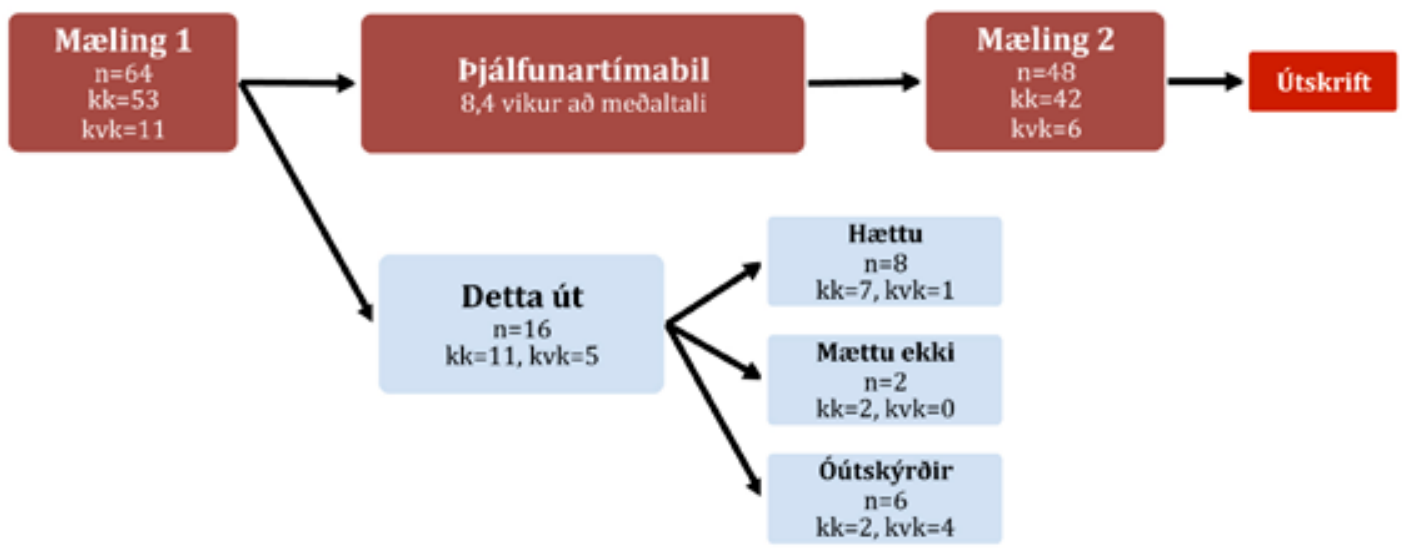

Mynd 1. Rannsóknarferlið

um rannsóknina og undirrituðu upplýst sampykki. Ekki var um að ræða viðmiðunarhóp sem ekki kom í pjálfun í pessari rannsókn.

\section{Forskoðun}

Í forskoðun var framkvæmt hámarksáreynslupróf á prekhjóli (Cardioline, Milano, Italy). Prektala (W/kg) var reiknuð út frá notuðu hámarksafli (Wött) sem hlutfall af líkamspyngd (kg). Í prófinu var blóðprýstingur (max/min slagbils- og panbilsprýstingur) mældur í upphafi, á mínútu fresti meðan á prófinu stóð og svo 1 lokin. Púls og hjartalínurit var mælt allan tímann með 12 leiðslu hjartalínuriti (Quinton, Bothell, WA, USA). Sjúklingar áttu helst að fara upp í 20 á Borg-kvarðanum og var miðað við að prófið tæki 8-12 mínútur. ${ }^{17}$ Tilgangurinn með pessu prófi var prípættur, a) ganga úr skugga um að í lagi væri að hefja pjálfun, b) komast að pví hvort sérstök ástæða væri til varúðar við pjálfun og c) meta afkastagetu til að nota við gerð pjálfunaráætlunar, en mælingar úr pessu prófi voru notaðar til að ákvarða pjálfunarálag (Wött) og pjálfunarpúls sjúklings. Pjálfunarpúls er púls sem sjúklingur átti að miða við að halda á mismunandi stigum pjálfunar. Karvonen-formúla var notuð ((PúlsMAX - PúlsMIN) x álagsprósenta + PúlsMIN = pjálfunarpúls), par sem álagsprósenta er prósenta af hámarksálagi á polprófi í upphafi rannsóknar. Ef pátttakandi/ sjúklingur átti að hjóla á 60\% álagi, var með 130 í hámarkspúls og 63 í lágmarkspúls átti að miða við að púlsinn væri í (130-63) x 60\%+63=103. Í forskoðun voru einnig skráðar upplýsingar um lyfjanotkun sjúklings, sjúkdóma, hvort hann væri með bjargrád/ gangráð og önnur atriði sem máli skiptu. Sjúklingum var raðað í æfingahópa eftir getu samkvæmt prektölu úr áreynsluprófi, aldri og fleiri páttum (sjá nánar í lýsingu á pjálfun).

\section{Mælingar}

Auk hámarksáreynsluprófs og mælinga á blóðprýstings- og púlssvörun voru eftirfarandi mælingar framkvæmdar:

Líkamspyngd var mæld með 0,1 kg nákvæmni með viðurkenndum pyngdarmæli og hæð með 0,1 cm nákvæmni með viðurkenndum hæðarmæli. Líkamspyngdarstuðull (body mass index, BMI) var reiknaður með pví að deila hæð í öðru veldi í líkamspyngd $\left(\mathrm{kg} / \mathrm{m}^{2}\right)$.
Til að meta heilsutengd lífsgæði var lagður fyrir SF-36v2 lífsgæðakvarðinn, en hann er sjálfsmat á andlegri og líkamlegri líðan. ${ }^{18}$ Andleg og líkamleg líðan skiptist í 8 undirpætti samkvæmt pessum kvarða. Líkamleg líðan skiptist í færni, virkni, verki og almenna líðan, en andleg í prótt og félagslega, tilfinningalega og andlega líðan.

Pær breytur sem notaðar voru í rannsókninni til að meta árangur hjartaendurhæfingarinnar voru prektala, líkamspyngdarstuðull, blóðprýstings- og púlssvörun og heilsutengd lífsgæði. Allar mælingar voru gerðar bæði við upphaf og lok pjálfunartímabilsins.

\section{Lýsing á Stig II pjálfun HL-stöđvarinnar}

Sjúklingar mæta í pjálfun að meðaltali prisvar í viku í fjórar til átta vikur. Hver tími er 45-50 mínútur. Skiptist hann pannig að fyrst er 25 mínútna pjálfun á hjóli eða göngubretti sem skiptist í a) upphitun, 7 mínútur á 30-35\% álagi, b) álag, 15 mínútur á 40/45-75\% álagi, c) kæling, 3 mínútur á 30-35\% álagi. Fylgst er með púlsi, blóðprýstingssvörun og almennri líðan á mismunandi tímapunktum, í upphafi, í miðjum álagskafla og í lokin. Fyrstu prjú skiptin er púls og hjartsláttur mæld með einnar leiðslu hjartalínuriti (Quinton) og ef engin hjartsláttaróregla kemur fram er skipt yfir á Polarpúlsmæli (Polar Electro, Kempele, Finland). Miða skal við álag

Tafla I. Grunnupplýsingar um pátttakendur

\begin{tabular}{lccc}
\hline & Lægsta gildi & Hæsta gildi & Meðaltal \\
\hline Fjöldi vikna í pjálfun & 5,0 & 20,9 & 8,4 \\
\hline Fjöldi skipta (á viku) & 0,4 & 3,0 & 2,1 \\
\hline Aldur (ár) & 32 & 86 & 65 \\
\hline Hæð (cm) & 160 & 192 & 177 \\
\hline Pyngd (kg) (Mæling 1) & 54 & 141 & 89,8 \\
\hline Pyngd (kg) (Mæling 2) & 54 & 140 & 89,5 \\
\hline $\begin{array}{l}\text { Líkamspyngdarstuðull (kg/m²) } \\
\text { (Mæling 1) }\end{array}$ & 21 & 44 & 29 \\
\hline Wött (Mæling 1) & 75 & 250 & 149 \\
\hline Wött (Mæling 2) & 90 & 288 & 169 \\
\hline & Konur & Karlar & Samtals \\
\hline Kynjaskipting pátttakenda (\%) & $6(13)$ & $42(87)$ & 48 \\
\hline
\end{tabular}


Tafla II. Mælingar fyrir og við lok pjálfunar.

\begin{tabular}{|c|c|c|c|c|c|c|}
\hline & Fjöldi (n) & Mæling 1 & Mæling 2 & Mismunur & Mismunur (\%) & p-gildi \\
\hline Prektala (W/kg) & 48 & $1,7 \pm 0,5$ & $1,9 \pm 0,5$ & $0,2 \pm 0,2$ & 14,4 & $<0,001$ \\
\hline 32-64 ára & 23 & $1,8 \pm 0,5$ & $2,1 \pm 0,6$ & $0,3 \pm 0,2$ & 14,6 & $<0,001$ \\
\hline 65-86 ára & 25 & $1,5 \pm 0,4$ & $1,7 \pm 0,4$ & $0,2 \pm 0,2$ & 14,1 & $<0,001$ \\
\hline Líkamspyngdarstuðull, kg/m² & 48 & $28,6 \pm 4,5$ & $28,5 \pm 4,4$ & $-0,1 \pm 0,6$ & $-0,4$ & 0,251 \\
\hline Lágmarkspúls & 48 & $67,7 \pm 10,9$ & $65,5 \pm 11,7$ & $-2,2 \pm 8,9$ & $-3,2$ & 0,095 \\
\hline Hámarkspúls & 48 & $125,2 \pm 22,0$ & $132,7 \pm 21$ & $7,6 \pm 14,5$ & 6,1 & 0,001 \\
\hline 32-64 ára & 23 & $135,5 \pm 20,2$ & $142,2 \pm 19,8$ & $6,7 \pm 14,9$ & 5,0 & 0,041 \\
\hline 65-86 ára & 25 & $115,6 \pm 19,4$ & $124,0 \pm 18,3$ & $8,4 \pm 14,3$ & 7,2 & 0,007 \\
\hline Slagbil (min) & 48 & $128 \pm 20$ & $133 \pm 21$ & $4,3 \pm 20,6$ & 3,4 & 0,150 \\
\hline Panbil (min) & 48 & $83 \pm 12$ & $83 \pm 10$ & $-0,7 \pm 11,6$ & $-0,8$ & 0,684 \\
\hline Slagbil (max) & 48 & $182 \pm 25$ & $186 \pm 27$ & $3,4 \pm 21$ & 1,9 & 0,269 \\
\hline Panbil (max) & 48 & $95 \pm 11$ & $94 \pm 14$ & $-0,1 \pm 11$ & $-0,1$ & 0,937 \\
\hline
\end{tabular}

Gildi: Meðaltal \pm staðalfrávik

12-15 á Borg-skala. ${ }^{17}$ Pessi hluti tímans er kjarninn í polpjálfun sjúklinganna. Eftir pessa 25 mínútna pjálfun er farið í tækjasal (einu sinni til tvisvar í viku) og ípróttasal (einu sinni til tvisvar í viku) par sem áherslan er meiri á styrk, jafnvægi og liðleika. Í tækjasal velja sjúklingar sér 8-10 líkamsræktartæki, setja sjálfir pá pyngd sem við á og framkvæma 15 endurtekningar á hverju peirra. Í ípróttasal er gjarnan stöðvapjálfun með 10-12 stöðvum, ein mínúta á stöð. Stöðvarnar eru fjölbreyttar, svo sem æfingar með boltum, handlóðum, teygjum, dýnuæfingum (kviður, bak), pallaæfingar og fleira sem pjálfarar leggja til. Í lok hvers tíma eru svo vöðvateygjur og púls og blóðprýstingur er skráður. Í síðasta tíma hverrar viku er vigtun.

Sjúklingar eru flokkaðir í áhættuflokka eftir útfallsbroti hjarta samkvæmt $\mathrm{AACVPR}^{19}$ og fleiri atriðum, svo sem hvort peir noti bjargráð/gangráð eða önnur atriði sem máli skipta fyrir pjálfunina. Pjálfarar sjá um að auka álag hægar hjá peim sem eru í aukinni áhættu. Eftirlit með pjálfunaráætlun og hjartalínuritum á pjálfunartímabilinu er í höndum sjúkrabjálfara. Ef hjartsláttaróregla eða einhvers konar vafatilfelli koma upp er pað skráð og haft samráð við lækni sem metur framhaldið.

Fræðslufundir eru haldnir reglulega, 5-8 á pjálfunartímabili, um ýmis efni, svo sem gildi pjálfunar, áhættupætti hjarta- og æðasjúkdóma, hjartalyf, streitu, næringu og fleira.
Sjúkrapjálfarar og læknar meta í sameiningu hvenær sjúklingur er tilbúinn til útskriftar en pað getur farið eftir ýmsu, svo sem breytingum á lyfjagjöf, blóðprýstingsvandamálum og fleiru, hversu fljótt peir útskrifast. Í pessari rannsókn voru svo sömu mælingar og gerðar voru í upphafi framkvæmdar aftur og pær bornar saman.

\section{Tölfræðiúrvinnsla}

Við úrvinnslu gagna var notað SPSS Statistic's útgáfa 21. Notað var parað t-próf (Paired-Samples T Test) og óháð t-próf (IndependentSamples T Test) til pess að bera saman breytur par sem um normaldreifð gögn var að ræða. Pegar pýðinu var skipt í tvo hópa eftir aldri, mati á andlegri og líkamlegri líðan eða fjölda skipta var fundið miðgildi sem skipti pýðinu í helminga og framkvæmt parað t-próf á hvorn hóp fyrir sig. Marktækni var miðuð við $1 \%$ marktektarmörk $(p<0,01)$

\section{Niðurstödur}

Dátttakendur og brottfall

Alls páðu 64 boð um að taka pátt í rannsókninni (af 65 sem var boðið) en 48 luku við allt rannsóknarferlið (mynd 1). Af pessum 48 svaraði 41 spurningalista SF-36v2 um lífsgæði á fullnægjandi hátt

Tafla III. Likamsmælingar eftir fjölda skipta.

\begin{tabular}{|c|c|c|c|c|c|c|c|c|}
\hline & \multicolumn{4}{|c|}{ 0,4 - 2,1 skipti í pjálfun ( $\mathrm{n}=25)$} & \multicolumn{4}{|c|}{ 2,2 - 3,0 skipti í pjálfun ( $\mathrm{n=23)}$} \\
\hline & Mæling 1 & Mæling 2 & Mismunur (\%) & p-gildi & Mæling 1 & Mæling 2 & Mismunur (\%) & p-gildi \\
\hline Prektala (W/kg meðaltal) & $1,8 \pm 0,5$ & $2,0 \pm 0,5$ & 10,1 & $<0,001$ & $1,5 \pm 0,4$ & $1,8 \pm 0,5$ & 19,8 & $<0,001$ \\
\hline Líkamspyngdarstuðull, kg/m² & $28,3 \pm 4,4$ & $28,3 \pm 4,4$ & 0,0 & 0,932 & $29,0 \pm 4,8$ & $28,7 \pm 4,5$ & $-0,8$ & 0,112 \\
\hline Lágmarkspúls & $68,0 \pm 10,1$ & $64,8 \pm 10,1$ & $-4,7$ & 0,080 & $67,2 \pm 12$ & $66,1 \pm 13,4$ & $-1,6$ & 0,574 \\
\hline Hámarkspúls & $129,9 \pm 19,1$ & $132,3 \pm 18,1$ & 1,8 & 0,323 & $120,0 \pm 24,1$ & $133,2 \pm 24,1$ & 11,0 & $<0,001$ \\
\hline Slagbil (min) & $133 \pm 22$ & $134 \pm 19$ & 0,7 & 0,786 & $124 \pm 16$ & $132 \pm 22$ & 6,5 & 0,119 \\
\hline Panbil (min) & $84 \pm 11$ & $81 \pm 9$ & $-3,8$ & 0,236 & $82 \pm 13$ & $84 \pm 11$ & 2,5 & 0,275 \\
\hline Slagbil (max) & $188 \pm 30$ & $187 \pm 30$ & $-0,3$ & 0,877 & $177 \pm 18$ & $185 \pm 23$ & 4,4 & 0,113 \\
\hline Panbil (max) & $95 \pm 12$ & $91 \pm 10$ & $-4,1$ & 0,073 & $94 \pm 10$ & $98 \pm 16$ & 4,2 & 0,080 \\
\hline
\end{tabular}

Gildi: Meðaltal \pm staðalfrávik 
Tafla IV Lifsgæðakvarði - SF-36v2.

\begin{tabular}{|c|c|c|c|c|c|c|}
\hline & Fjöldi (n) ${ }^{1}$ & Mæling 1 & Mæling 2 & Mismunur & Mismunur (\%) & $\mathrm{p}$-gildi \\
\hline Líkamleg líđan (PCS) ${ }^{3}$ & 41 & $47,7 \pm 7,1$ & $51,2 \pm 6,5$ & $3,4 \pm 6,9$ & 7,2 & 0,003 \\
\hline $0,4-2,1$ skipti & 21 & $48,7 \pm 7,7$ & $51,5 \pm 6,3$ & $2,9 \pm 7,3$ & 5,9 & 0,090 \\
\hline 2,2 - 3,0 skipti & 20 & $46,8 \pm 6,6$ & $50,8 \pm 6,9$ & $4,0 \pm 6,6$ & 8,6 & 0,014 \\
\hline Verri líđan í upphafi² & 20 & $42,1 \pm 5,1$ & $48,4 \pm 6,2$ & $6,4 \pm 7,9$ & 15,1 & 0,002 \\
\hline Betri líđan í upphafi² & 21 & $53,1 \pm 3,7$ & $53,8 \pm 5,9$ & $0,6 \pm 4,4$ & 1,2 & 0,523 \\
\hline Andleg líðan (MCS) ${ }^{4}$ & 41 & $52,0 \pm 8,0$ & $53,1 \pm 7,3$ & $1,1 \pm 7,2$ & 2,2 & 0,314 \\
\hline $0,4-2,1$ skipti & 21 & $54,3 \pm 5,6$ & $55,4 \pm 6,1$ & $1,1 \pm 6,4$ & 2,0 & 0,446 \\
\hline 2,2 - 3,0 skipti & 20 & $49,5 \pm 9,4$ & $50,7 \pm 7,8$ & $1,2 \pm 8,1$ & 2,4 & 0,515 \\
\hline
\end{tabular}

141 af 48 svaraði báðum spurningalistum á fullnægjandi hátt.

${ }^{2}$ Sjálfsmati á líkamlegri líđan skipt í tvo flokka: 1) einkunn 29-47 og 2) einkunn 48-60. Hærri tala pýðir betri líðan.

3PCS: Physical component summary.

${ }^{4} \mathrm{MCS}$ : Mental component summary.

í upphafi og við lok pjálfunar, svo niðurstöður úr peim hluta eiga eingöngu við pá. Kynjaskiptingin var 42 karlar og 6 konur. Peir 16 sem heltust úr lestinni (11 karlar og 5 konur) hættu ýmist fyrir lok rannsóknar eða mættu ekki í fyrsta tíma eftir að áreynslupróf hafði verið gert. Pjálfunartímabilið var frá 5 vikum upp í 20,9 vikur, eða að meðaltali 8,4 vikur (tafla I).

\section{Líkamsmælingar og pjálfun}

Prektala hækkaði um 14,4\% (p<0,001) og 6,1\% aukning varð á hámarkspúlsi $(\mathrm{p}=0,001)$ eftir pjálfunartímabilið pegar litið er á hópinn í heild (tafla II). Ef hópnum er skipt eftir aldri (32-64 ára og 65-86 ára) bættu báðir aldurshópar sig svipað í prektölu (14,6\% og $14,1 \%$ ) en pað var eingöngu eldri hópurinn sem jók hámarkspúls marktækt, eða um 7,2\% ( $\mathrm{p}=0,007)$.

Í töflu III er hópnum skipt eftir pví hversu oft peir æfðu á viku (0,4-2,1 og 2,2-3,0 skipti). Pá má sjá 10,1\% aukningu á prektölu hjá hópnum sem æfði sjaldnar, en 19,8\% hjá peim sem æfðu oftar ( $\mathrm{p}<0,001$ í báðum tilvikum). Eins er marktæk hækkun um 11\% á hámarkspúlsi hjá peim sem æfðu oftar $(\mathrm{p}<0,001)$ en ekki hjá peim sem æfðu sjaldnar (1,8\%).

\section{Heilsutengd lífsgæð $i$}

Í töflu IV má sjá niðurstöður úr spurningalista um lífsgæði, SF-36v2. Heildarstigum kvarðans hefur verið umbreytt í T-ein-

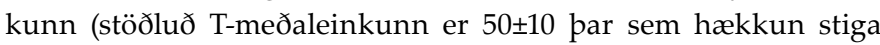
gefur til kynna meiri lífsgæði). Pátttakendur mátu líkamlega líðan betri við lok pjálfunar, eða um $7,2 \%$ ( $p=0,003)$, en ekki andlega líðan ( $p=0,314)$. Pegar hópnum er skipt í tvo hópa eftir pví hvernig peir mátu líkamlega líðan í upphafi rannsóknar sést marktæk hækkun um 15,1\% á líkamlegri líðan hjá peim sem mátu sig í verri stöðu í upphafi ( $\mathrm{p}=0,002)$, en hinn hópurinn hækkaði um 1,2\%. Prektala peirra sem mátu líkamlega líðan verri í upphafi var pó ekki marktækt lægri en hinna.

\section{Umræða}

Niðurstöður sýna að peir hjartasjúklingar sem tóku pátt í pessari rannsókn bættu prek og hámarkspúls eftir Stig II pjálfun í kjölfar hjartaaðgerða eða kransæðavíkkunar. Sjúklingar mátu auk pess líkamlega líðan betri í lok pjálfunar en ekki andlega samkvæmt skori á lífsgæðakvarða SF-36v2. Peir sjúklingar sem mættu oftar í pjálfun bættu sig meira en hinir í preki og hámarkspúlsi og peir meta einnig líkamlega líðan betri.

Eins og fram kemur í nýlegum yfirlitsgreinum um kransæðasjúkdóma á Íslandi eru peir meðal algengustu langvinnra sjúkdóma hér. ${ }^{3,4}$ Pótt dauðsföllum vegna peirra hafi fækkað ${ }^{20}$ er kransæðastífla langalgengasta dánarorsök hér á landi. Árlega eru gerðar 600-700 kransæðavíkkanir á Landspítala.,4 pörfin fyrir hjartaendurhæfingu er pví mikil og mikilvægt að pau úrræði sem til staðar eru séu vandlega ígrunduð og notuð á réttan hátt. Pessi rannsókn getur ótvírætt aðstoðað við pað.

Í skýrslu fagráðs um heilsueflingu á vegum Landlæknisembættisins frá 2003 er bent á að nægar vísindalegar sannanir bendi til pess að reglubundin hreyfing með miðlungsálagi sé virk forvörn og jafnvel hluti meðferðar gegn hjarta- og æðasjúkdómum, svo sem kransæðastíflu, heilablóðfalli, æðaprengslum í ganglimum og háprýstingi. ${ }^{21}$

Margar rannsóknir hafa verið gerðar á sviði hjartaendurhæfingar á undanförunum árum og styðja pær við niðurstöður pessarar sem framkvæmd var á HL-stöðinni..$^{5-7}$ Í safngreiningu 6 samanburðarrannsókna á áhrifum pjálfunar á 276 hjartasjúklinga bættu sjúklingarnir prek og heilsutengd lífsgæði í kjölfar pjálfunar, en ekki kom fram marktæk breyting á slagbils- eða panbilsblóðprýstingi. ${ }^{22}$ Sólrún Jónsdóttir og félagar birtu árið 2006 niðurstöður rannsóknar á áhrifum hjartaendurhæfingar á íslenska sjúklinga með hjartabilun. Par var pjálfunartímabilið lengra og lengri tími milli pjálfunartíma. Pessir sjúklingar bættu getu sína á prekhjóli, 6 mínútna gönguprófi og einnig líkamleg lífsgæði. ${ }^{23}$

Rannsóknin sýnir fram á að pað skilar auknum árangri að æfa oftar. Pað er í samræmi við rannsókn par sem sjúklingum sem gengust undir kransæðavíkkun var skipt í prjá hópa sem æfðu 5, 10 eða 25 sinnum eftir aðgerð. ${ }^{24}$ Allir hópar sýndu eftir æfingatímabilið marktæka bætingu á ýmsum páttum en eftir pví sem æfingarnar voru fleiri pví meira bættu sjúklingarnir sig. Nýleg rannsókn á yfir 30.000 einstaklingum sýndi að peir sem mættu í endurhæfingu í 36 skipti höfðu 14\% lægri dánartíðni pegar peir voru bornir saman við pá sem fóru í 24 skipti eða sjaldnar í hjartaendurhæfingu. Pá höfðu peir sem fóru í 36 skipti 22\% lægri dánartíðni pegar peir voru bornir saman við pá sem fóru í 12 skipti eða sjaldnar og 47\% lægri dánartíðni pegar peir voru bornir saman við 
pá sem mættu eingöngu í eitt skipti eða sjaldnar. ${ }^{25}$ Peir sem bjóða upp á hjartaendurhæfingu purfa að finna leiðir til að ná fram betri mætingu, til dæmis mætti taka upp pá aðferð að hringja í pá sem hafa ekki mætt tvö skipti í röð. ${ }^{26}$ Hjá HL-stöðinni er miðað við prjú skipti í viku í 4-8 vikur (12-24 skipti). Samkvæmt ofangreindri rannsókn mætti hugsanlega ná betri árangri með pví til dæmis að lengja tímabilið, en auðvitað hljóta aðferðir, magn og fleiri pættir að skipta miklu máli.

Áhugaverðar niðurstöður rannsóknarinnar eru meðal annars pær að eldri hópurinn er að bæta hámarkspúls meira en sá yngri, en bætt prek er mjög svipað í báðum hópunum. Hugsanleg skýring á pví að eldri hópurinn er að bæta hámarkspúls meira gæti að hluta til verið sú að peir mættu að meðaltali 23,7\% oftar í pjálfun en yngri hópurinn $(\mathrm{p}=0,017)$ en eins og áður sagði varð meiri bæting eftir pví sem mætt var oftar í pjálfun. Pessar niðurstöður eru einnig í samræmi við aðra rannsókn par sem yngri sjúklingar $(<55$ ára) og eldri (>70 ára) voru bornir saman og í ljós kom að eldri sjúklingarnir bættu sig marktækt meira en peir yngri, bæði hvað varðar virkni og lífsgæði. ${ }^{27}$

Aðrir sjúkdómar, svo sem punglyndi og offita, geta haft áhrif á árangur svona meðferða. Í erlendri safngreiningu voru könnuð áhrif pess að hafa sálfélagslega meðferð sem hluta af endurhæfingu. Í ljós kom að dánartíðni var minni hjá peim sjúklingum sem fengu sálfélagslega meðferð samhliða pjálfun. ${ }^{28}$ Í annarri rannsókn voru bornir saman sjúklingar sem pjáðust af offitu (BMI >27 $\mathrm{kg} / \mathrm{m}^{2}$ ) og peir sem gerðu pað ekki, og hækkaði prektala marktækt meira hjá síðarnefnda hópnum. ${ }^{29}$ Í pessari rannsókn var líkamspyngdarstuðull að meðaltali 29 svo hugsanlega gætir einhverra áhrifa vegna pess á niðurstöðurnar.

Meðal styrkleika rannsóknarinnar er að ekki var eingöngu um mælingar að ræða, heldur einnig sjálfsmat. Pjálfunin er markviss og vel skilgreind, sérstaklega sá hluti hennar sem snýr að polpjálfuninni. Meðal takmarkana rannsóknarinnar var að ekki var neinn viðmiðunarhópur sem ekki fékk neina pjálfun. Pegar haft er í huga hvað hjartaendurhæfing er viðurkennd meðferð, er pað ekki siðferðislega rétt að hafa slíkan viðmiðunarhóp. Gagnlegt hefði verið að endurtaka polpróf og lífsgæðamat eftir 3-6 mánuði til að kanna hvort árangur endurhæfingarinnar endist. Fáar konur tóku pátt í rannsókninni sem skýrist af pví að færri konur en karlar leita almennt á HL-stöðina. En hvers vegna svo fáar konur leita pangað er umhugsunarefni. Mögulega fara pær annað eða stunda hreyfingu heima við og svo gæti verið að pær séu ófúsari en karlar til að hefja pessa pjálfun. Rannsóknir hafa sýnt að ein af ástæðunum fyrir minni pátttöku kvenna sé sú að pær fái ekki eins mikla hvatningu og karlar og sjaldnar tilvísanir prátt fyrir að vera jafnvel metnar hæfari fyrir slíka pjálfun. ${ }^{30,31}$ Erfitt er að meta áhrif dræmrar pátttöku kvenna á pessa rannsókn en ljóst er að munur er á kynjunum hvað varðar hjartasjúkdóma og dánartíðni. 32,33

Brottfall var $25 \%$, par af $12,5 \%$ sem hættu einhvern tímann á tímabilinu, 3,1\% mættu ekki í fyrsta tíma eftir að fyrsta mat með áreynsluprófi hafði verið gert en 9,4\% eru óútskýrðir. Ástæður brottfalls hafa verið kannaðar í erlendum rannsóknum og voru samgönguerfiðleikar, tryggingamál og pað að eiga líkamsræktartæki heima við helstu ástæður sem nefndar voru. ${ }^{31}$ Hér á landi gætu samgönguerfiðleikar vissulega verið einn páttur, en pað er varla eina skýringin. Velta má fyrir sér hvort vanti upp á fræðslu um ávinning af meðferð og hvatningu í fyrstu tímum, eða hvort skýringuna megi finna annars staðar. Ekki var haft samband við pá sem hættu í pessari rannsókn en í seinni rannsóknum væri fróðlegt að kanna pað betur.

Nokkur munur er á lengd pjálfunartímabilsins, eða frá 5 og upp i 20,9 vikur. Ástæður pess að tímabilið er svona langt hjá nokkrum aðilum voru ekki kannaðar, en pó eru fjórir sem lenda á sumarfrístímabili HL-stöðvarinnar. Peir sem lenda á pví fá pó ráðleggingar um hreyfingu í fríinu og er jafnvel vísað til sjúkrapjálfara á meðan. Ekki er pví talið að pessi mismunandi lengd pjálfunartímabils hafi áhrif á niðurstöður.

Í samantekt má sjá að hjartasjúklingar pessarar rannsóknar bæta prek með hjartaendurhæfingu í kjölfar hjartaaðgerða eða kransæðavíkkunar. Peir meta auk pess líkamlega líðan betri í lok pjálfunar. Peir sjúklingar sem mættu oftar í pjálfun náðu meiri bata og líkamleg líðan peirra varð betri.

\section{Pakkir}

Pátttakendur í rannsókninni fá pakkir fyrir gott samstarf. Elín S. Steinarsdóttir ritari á HL-stöðinni fyrir mikla og góða aðstoð við að leggja fyrir og halda utan um spurningalistana. Einnig annað starfsfólk HL-stöðvar. Eyrún Torfadóttir nýdoktor og tölfræðingur fyrir aðstoð við tölfræðilega úrvinnslu. 


\section{Heimildir}

1. Mozaffarian D, Benjamin EJ, Go AS, Arnett DK, Blaha MJ, Cushman $M$, et al. Heart disease and stroke statistics - 2015 update: a report from the American Heart Association. Circulation 2015; 131: e29-e322.

2. WHO । The Atlas of Heart Disease and Stroke. WHO at who.int/cardiovascular_diseases/resources/atlas/en/ ágúst 2015.

3. Guðbjartsson T, Andersen K, Danielsen R, Geirsson A. Yfirlitsgrein um kransæðasjúkdóm - fyrri hluti: Faraldsfræði, meingerð, einkenni og rannsóknir til greiningar. Læknablaðið 2013; 100: 667-76.

4. Guðbjartsson T, Andersen K, Danielsen R, Geirsson A. Yfirlitsgrein um kransæđasjúkdóm - síðari hluti Lyfjameðferð, kransæðavíkkun og kransæðahjáveituaðgerð. Læknablaðið 2014; 101: 25-35.

5. Anderson LJ, Taylor RS. Cardiac rehabilitation for people with heart disease: An overview of Cochrane systematic reviews. Int J Cardiol 2014; 177: 348-61.

6. Gielen S, Laughlin MH, $\mathrm{O}^{\prime}$ Conner C, Duncker DJ. Exercise training in patients with heart disease: review of beneficial effects and clinical recommendations. Prog Cardiovasc Dis 2015; 57: 347-55.

7. Menezes AR, Lavie CJ, Forman DE, Arena R, Milani RV, Franklin BA. Cardiac rehabilitation in the elderly. Prog Cardiovasc Dis 2014; 57: 152-9.

8. Ámundadóttir ÓR. Samanburður á tveimur aðferđum við endurhæfingu á hjartasjúklingum. [M.S. ritgerð] - Hirsla - Landspítali. hirsla.lsh.is/lsh/handle/2336/55333 - ágúst 2015.

9. Wenger NK. Current status of cardiac rehabilitation. J Am Coll Cardiol 2008; 51: 1619-31.

10. Williams MA, Ades PA, Hamm LF, Keteyian SJ LaFontaine TP, Roitman JL, et al. Clinical evidence for a health benefit from cardiac rehabilitation: An update. Am Heart J 2006; 152: 835-41.

11. Taylor RS, Brown A, Ebrahim S, Jolliffe J, Noorani H, Rees $\mathrm{K}$, et al. Exercise-based rehabilitation for patients with coronary heart disease: systematic review and metaanalysis of randomized controlled trials. Am J Med 2004; 116: 682-92.

12. Cardiac rehabilitation programs. A statement for healthcare professionals from the American Heart Association. Circulation 1994; 90: 1602-10.
13. Kristjánsdóttir Á, Ingvarsdóttir I. Endurhæfing eftir hjartaaðgerð. 2001. hjartaheill.is/images/stories/annad/ endurh_e_hjartaadg.pdf - ágúst 2015.

14. Bjarnason-Wehrens $B$, McGee $\mathrm{H}$, Zwisler AD, Piepol MF, Benzer W, Schmid JP, et al. Cardiac rehabilitation in Europe: results from the European Cardiac Rehabilitation Inventory Survey. Eur J Cardiovasc Prev Rehabil 2010; 17: 410-8.

15. Fletcher $\mathrm{GF}^{1}$, Ades PA, Kligfield P, Arena R, Balady GJ, Bittner VA, et al. Exercise Standards for Testing and Training A Scientific Statement From the American Heart Association. Circulation 2013; 128: 873-934.

16. Balady GJ, Ades PA, Bittner VA, Franklin BA, Gordon NF, Thomas RJ, et al. Referral, Enrollment, and Delivery of Cardiac Rehabilitation/Secondary Prevention Programs at Clinical Centers and Beyond A Presidential Advisory From the American Heart Association. Circulation 2011; 124: 2951-60.

17. Borg G. Psychophysical scaling with applications in physical work and the perception of exertion. Scand J Work Environ Health 1990; 16 Suppl 1: 55-8

18. Ware J, Kosinski M, Keller S. SF-36 physical and mental health summary scales: a user's manual. 1994.

19. AACVPR Risk Stratification Algorithm for Risk of Event https://www.aacvpr.org/Portals/0/Registry/AACVPR\%20 Risk\%20Stratification\%20Algorithm_June2012.pdf - ágúst 2015 .

20. Aspelund T, Gudnason V, Magnusdottir BT, Andersen K, Sigurdsson G, Thorsson B, et al. Analysing the large decline in coronary heart disease mortality in the Icelandic population aged 25-74 between the years 1981 and 2006. PLoS ONE 2010; 5: e13957.

21. Embætti landlæknis. Áherslur til heilsueflingar - Ný skýrsla. landlaeknir.is/um-embaettid/frettir/frett/item 16800 - ágúst 2015.

22. Pandey A, Parashar A, Kumbhani DJ, Agarwal S, Garg J, Kitzman D, et al. Exercise training in patients with heart failure and preserved ejection fraction meta-analysis of randomized control trials. Circ Heart Fail 2015; 8: 33-40.

23. Jónsdóttir S, Andersen KK, Sigurðsson AF, Sigurðsson SB. The effect of physical training in chronic heart failure. Eur J Heart Fail 2006; 8: 97-101.
4. Soleimani A, Salarifar M, Kasaian SE, Sadeghian S, Nejatian M, Abbasi A. Effect of completion of cardiac rehabilitation on heart rate recovery. Asian Cardiovasc Thorac Ann 2008; 16: 202-7.

25. Hammill BG, Curtis LH, Schulman KA, Whellan DJ Relationship between cardiac rehabilitation and longterm risks of mortality and myocardial infarction among elderly medicare beneficiaries. Circulation 2010; 121: 63-70.

26. ter Hoeve N, Huisstede BM, Stam HJ, van Domburg RT, Sunamura M, van den Berg-Emons RJ. Does cardiac rehabilitation after an acute cardiac syndrome lead to changes in physical activity habits? Systematic review. Phys Ther 2015; 95: 167-79.

27. Lavie CJ, Milani RV. Disparate effects of improving aerobic exercise capacity and quality of life after cardiac rehabilitatin in young and elderly coronary patients. J Cardiopulm Rehabil 2000; 4: 235-40.

28. Linden W, Stossel C, Maurice J. Psychosocial interventions for patients with coronary artery disease. A Meta-analysis. Arch Intern Med 1996; 156: 745-52.

29. Lavie CJ, Milani RV. Effects of cardiac rehabilitation, exercise training, and weight reduction on exercise capacity, coronary risk factors, behavioral characteristics, and quality of life in obese coronary patients. Am J Cardiol 1997; 79: 397-401.

30. Ades PA, Waldmann ML, Polk DM, Coflesky JT. Referral patterns and exercise response in the rehabilitation of female coronary patients aged $\geq 62$ years. Am J Cardiol 1992; 69: 1422-5.

31. Halm M, Penque S, Doll N, Beahrs M. Women and cardiac rehabilitation: referral and compliance patterns. J Cardiovasc Nurs 1999; 13: 83-92.

32. van Lennep JER, Westerveld HT, Erkelens DW, van der Wall EE. Risk factors for coronary heart disease: implications of gender. Cardiovasc Res 2002; 53: 538-49.

33. Lerner DJ, Kannel WB. Patterns of coronary heart disease morbidity and mortality in the sexes: A 26-year follow-up of the Framingham population. Am Heart J 1986; 111: 38390

\section{ENGLISH SUMMARY}

\section{Effect of cardiac rehabilitation following coronary bypass surgery or other coronary interventions}

Fríða Dröfn Ammendrup ${ }^{1}$, Mundína Ásdís Kristinsdóttir², Gunnar Guðmundsson²,3, Erlingur Jóhannsson

Introduction: Cardiac rehabilitation is a well-established treatment for patients with coronary artery disease but limited information is available for Icelandic patients. The aim of this study was to investigate whether Phase II cardiac rehabilitation at the HL rehabilitation center was improving physical health and quality of life of patients.

Material and methods: Patients that had undergone coronary artery intervention were invited to participate. There were 64 participants (of 65 invited) that started in the study and 48 that finished. On average participants attended 2.1 sessions pr. week, for 8.4 weeks. Measurements performed: endurance $(\mathrm{W} / \mathrm{kg})$, blood pressure and pulse responses from an exercise test and body mass index $\left(\mathrm{kg} / \mathrm{m}^{2}\right)$. To measure health related quality of life the SF-36v2 questionnaire was used.

Results: Endurance improved by $14.4 \%(p<0,001)$ and a $6.1 \%$ increase was seen in peak pulse $(p=0.001)$. The group was divided by age $(32-64$ years and 65-86 years) and both age groups improved their endurance number similarly (14.6\% and $14.1 \%)$ but only the older age group improved peak pulse significantly or $7.2 \%(p=0.007)$. When the group was divided according to number of training sessions per week there was a $10.1 \%$ increase in endurance in the group that had fewer sessions but it was $19.8 \%$ in those that attended more sessions $(p<0.001)$. Participants assessed that their physical health, measured with a questionnaire, had improved at the end of training $(p=0.003)$. When the group was divided into two groups according to how they measured their physical health at the beginning of the study there was a significant increase of $15.1 \%$ in physical health in those that estimated worse quality of life at the beginning of the study, but the other group had an increase of $1.2 \%$. Conclusion: Cardiac rehabilitation improves endurance and physical wellbeing in patients. Training magnitude is essential for improvement. 